\title{
Development of Silk Business in South Sulawesi Province
}

\author{
Nuraeni Kadir ${ }^{1}$, Abdul Razak Munir ${ }^{2}$, Fauziah Umar ${ }^{3}$, Jumidah Maming ${ }^{4}$ \\ \{nuraeinikadir@gmail.com, arazak.munir@gmail.com,umar.fauziah@yahoo.com, \\ jumidahmaming@yahoo.com \} \\ Faculty of Economics and Business, Hasanuddin University
}

\begin{abstract}
The business of silk is demanded to be more aggressive. This research aims to determine what is the assessment of criteria that determine the decision-making model for development of the silk business in Wajo and analyze the results of ranking of the decisions on the model of business development in the silk business. The population as amount 544 people. The sample was determined by 235 respondents through the Slovin formula. Analysis of the data used is AHP and MPE. The results of the study show the assessment of the criteria that determine of the business development model of the tuning from the hierarchical analysis of the selected process six criteria on the business development model of the sequestration. This six criteria include training programs, supply of silk raw materials, innovation in developing human resources, government policy support the silk business, involvement of national and multinational companies and availability of capital.
\end{abstract}

Keywords: Evaluation, Model, Development of the Silk Business

\section{Introduction}

The main problem that has been examined in this study is how the decisions' results implemented on the business development model of the business in Wajo Regency. The specific objective of this research is to find out what is the assessment of the criteria that determine the decision making of the business development model in Wajo Regency; The urgency of this research is aimed at establishing a business development model for the business of the Wajo Regency, South Sulawesi Province. The goal is to develop, evaluate, and create a business development model, have product quality, and increase income. The business development used shows that the business development strategy in Wajo Regency is in quadrant I, namely, the aggressive its strategy. It means that the business is demanded to be more aggressive in using its business strengths to face vast market opportunities in entrepreneurial activities in the scooter development in Wajo Regency.

This research is an exploratory study that seeks to find relatively new and explanatory relationships, namely research conducted by explaining the symptoms caused by a research object. In terms of the data aspect, it is ex post facto research, which means it is a systematic empirical search after the incident. In terms of its objective, it is a causal study that seeks to explain entrepreneurial perceptions and strategies for developing a scooter business in Wajo Regency, South Sulawesi Province.

The population in this study were 544 silk weavers who run a business. The sample is a collection of sampling units selected from a sampling frame. Emory and Cooper (1991) suggest that the sample is part of the population that is carefully chosen to represent the 
population [1]. Singarimbun (1995) [2] states that survey research takes a sample from a population and uses a questionnaire as the primary data collection tool. The study uses the Slovin formula as follows. The data analysis used for this research is descriptive, AHP, and MPE.

\section{Result}

Analysis of the research results has been done through the Analysis Hierarchy Process (AHP) and the Exponential Comparison Method (MPE) to get the right model in developing the business in the district of Wajo. The weighting of each criterion involved in AHP analysis can be calculated manually or using the help of Expert Choice v11 software. Weighting using Expert Choice v11. The Eigenvector Calculation Table and the Maximum Eigenvalues and Consistency Ratio value testing results from weighting using Expert Choice v11 show that the final results of data processing based on the AHP method are as follows:

Table 1. Weighted Priority in Each Criterion

\begin{tabular}{lc}
\hline \multicolumn{1}{c}{ Criteria } & Priority weight \\
\hline Training program & 0.249 \\
Raw material supply & 0.211 \\
Human resource development innovation & 0.178 \\
Government policy & 0.169 \\
Company involvement & 0.135 \\
Venture capital & 0.122 \\
\hline
\end{tabular}

Consistency Ratio $=0.009$ 
From the table above, it is noticeable that each alternative's priority weighted can be obtained from the data processing above against each of the existing criteria (training programs, raw material supply, human resource development innovations, government policies, company involvement, and venture capital). The results of the priority weight of each alternative are asfollows:

Table 2. Weighted Priority of Each Model on The Training Program

\begin{tabular}{ccccccc}
\hline & \multicolumn{5}{c}{ Priority } \\
\cline { 2 - 7 } Alternative & $\begin{array}{c}\text { Training } \\
\text { Program }\end{array}$ & $\begin{array}{c}\text { Raw } \\
\text { Material } \\
\text { Supply }\end{array}$ & $\begin{array}{c}\text { Human } \\
\text { Resource } \\
\text { Development } \\
\text { Innovation }\end{array}$ & $\begin{array}{c}\text { Government } \\
\text { Policy }\end{array}$ & $\begin{array}{c}\text { Company } \\
\text { Involvement }\end{array}$ & $\begin{array}{c}\text { Venture } \\
\text { Capital }\end{array}$ \\
\hline Model 1 & 0.229 & 0.251 & 0.334 & 0.301 & 0.324 & 0.439 \\
Model 2 & 0.218 & 0.365 & 0.429 & 0.397 & 0.416 & 0.642 \\
Model 3 & 0.121 & 0.194 & 0.357 & 0.246 & 0.347 & 0.569 \\
$\begin{array}{l}\text { Consistency } \\
\text { Ratio }\end{array}$ & 0.044 & 0.033 & 0.010 & 0.021 & 0.014 & 0.000 \\
\hline
\end{tabular}

Then from the table 2, it can be generated the overall or aggregate weight of the alternatives against all existing criteria. It can be seen that the consistency ratio value on the priority weight varied from one criterion to another. For the training program is 0.044 , motivation is 0.033 , HR development innovation is 0.010 , government policy is 0.021 , company involvement is 0.014 , and venture capital is 0.000 , which means it has significant consistency where the $\mathrm{CR}$ (consistency ratio) value must be $<0.05$. For the dominant priority, weight is business capital as a priority decision in the spinning business development model. The results of the aggregate weight of eachalternative are as follows:

Table 3. GlobalWeights for Each Model

\begin{tabular}{cc}
\hline Alternative & Aggregate Weight \\
\hline Model 1 & 0.313 \\
Model 2 & 0.411 \\
Model 3 & 0.306 \\
\hline Consistency Ratio $=0.009$ & \\
\hline
\end{tabular}

From the results of data processing obtained the highest priority weight for the criteria is the training program criteria (0.249). The magnitude of each criterion's weight from the largest to the smallest can be seen in Table 25. From the results of data processing, the global weight of each alternative is also obtained. It can be seen in Table 27. model 2 (0.411). Model 2 has a greater value than model $1(0.313)$ and model $3(0.306)$. In this case, model 2 has a better preference than model 1 and model 3 for all existing criteria, which is caused 
because model 2 is superior to each of the criteria than model 1 and model 3.

Table 4. Final Weighted Results for Models 1, 2 and 3

\begin{tabular}{lccc}
\hline \multicolumn{1}{c}{ Criteria } & Model 1 (0.313) & Model 2 (0.411) & Model 3 (0.306) \\
\hline Training Program & 0.229 & 0.218 & 0.121 \\
Raw Material Supply & 0.251 & 0.365 & 0.194 \\
Human Resource Development & 0.334 & 0.429 & 0.357 \\
Innovation & 0.301 & 0.397 & 0.246 \\
Government Policy & 0.324 & 0.416 & 0.347 \\
Company Involvement & 0.439 & 0.642 & 0.569 \\
Venture Capital & & & \\
\hline
\end{tabular}

\section{Exponential Comparison Method}

In this study, Exponential Comparison Method counts the 6 (six) criteria that have been selected are calculated. By using existing data on alternatives and standards, the following results are obtained:

$$
\begin{aligned}
& \text { Training Program } \\
& \begin{aligned}
T N_{1} & =R K_{11}{ }^{T K K 1}+R K_{12}{ }^{T K K 2}+R K_{13}{ }^{T K K 3}+R K_{14}{ }^{T K K 4}+R K_{15}{ }^{T K K 5}+R K_{16}{ }^{T K K 6} \\
& =3^{0.249}+4^{0.211}+5^{0.178}+3^{0.169}+3^{0.135}+4^{0.122} \\
& =1.31+1.34+1.33+1.20+1.16+1.18 \\
& =7.53
\end{aligned}
\end{aligned}
$$

Raw Material Supplay

$$
\begin{aligned}
T N_{2} & =R K_{21}{ }^{T K K 1}+R K_{22}{ }^{T K K 2}+R K_{23}{ }^{T K K 3}+R K_{24}{ }^{T K K 4}+R K_{25}{ }^{T K K 5}+R K_{26}{ }^{T K K 6} \\
& =3^{0.249}+5^{0.211}+4^{0.178}+4^{0.169}+3^{0.135}+5^{0.122} \\
& =1.31+1.40+1.28+1.16+1.16+1.22 \\
& =7.64
\end{aligned}
$$

Human Resource Development Innovation

$$
\begin{aligned}
T N_{3} & =R K_{31}{ }^{T K K 1}+R K_{32}{ }^{T K K 2}+R K_{33}{ }^{T K K 3}+R K_{34}{ }^{T K K 4}+R K_{35}{ }^{T K K 5}+R K_{36}{ }^{T K K 6} \\
& =4^{0.249}+4^{0.211}+5^{0.178}+3^{0.169}+5^{0.135}+4^{0.122} \\
& =141+1.34+1.33+1.20+1.24+1.18 \\
& =7.71
\end{aligned}
$$

Government Policy

$$
\begin{aligned}
T N_{4} & =R K_{41}{ }^{T K K 1}+R K_{42}{ }^{T K K 2}+R K_{43}{ }^{T K K 3}+R K_{44}{ }^{T K K 4}+R K_{45}{ }^{T K K 5}+R K_{46}{ }^{T K K 6} \\
& =4^{0.249}+3^{0.211}+5^{0.178}+5^{0.169}+4^{0.135}+3^{0.122} \\
& =1.41+1.26+1.33+1.31+1.21+1.14 \\
& =7.67
\end{aligned}
$$

Company Involvement 


$$
\begin{aligned}
T N_{5} & =R K_{51}{ }^{T K K 1}+R K_{52}{ }^{T K K 2}+R K_{53}{ }^{T K K 3}+R K_{54}{ }^{T K K 4}+R K_{55}{ }^{T K K 5}+R K_{56}{ }^{T K K 6} \\
& =4^{0.249}+3^{0.211}+5^{0.178}+5^{0.169}+4^{0.135}+4^{0.122} \\
& =1.41+1.26+1.33+1.31+1.21+1.18 \\
& =7.71
\end{aligned}
$$

Venture Capital

$$
\begin{aligned}
T N_{6} & =R K_{61}{ }^{T K K 1}+R K_{62}{ }^{T K K 2}+R K_{63}{ }^{T K K 3}+R K_{64}{ }^{T K K 4}+R K_{65}{ }^{T K K 5}+R K_{66}{ }^{T K K 6} \\
& =3^{0.249}+5^{0.211}+5^{0.178}+5^{0.169}+4^{0.135}+5^{0.122} \\
& =1.31+1.40+1.33+1.31+1.21+1.22 \\
& =7.79
\end{aligned}
$$

Then the ranking of decisions is obtained, which should take precedence. As it is known, the decision-making method that quantifies a person's opinion or more on an absolute scale, which in principle is a method of scoring the available options. Exponentially, the difference in value between criteria can be distinguished depending on the ability of the assessor. The results of the decision were TN6 - TN3 - TN5 - TN4 - TN2 - TN1

This result means that in making decisions for a silk business's business development model, the business developer must first determine the amount of venture capital for the silk business, then innovate in developing human resources. In this case, it increases the knowledge, skills, and attitudes of silk artisans in running the silk business. These are inseparable from the involvement of both national and multinational companies in participating in advancing the silk business and policy support from the government in developing silk businesses. Apart from that, it supplies silk raw materials and creates training programs for workers to sustain the silk business in the future.

\section{Discussion}

In this case, the business's development plan uses AHP and MPE analysis. AHP aims to provide an assessment of the criteria that determine the business development model for the company. The methodology's choice based on the characteristics of the problem and the consideration of its advantages and disadvantages. Researchers assess the importance of each criterion according to the value of the pair of standards being compared. The final result of AHP is a ranking or priority weighting of each alternative model. The assessment criteria are expected to indicate the quality or level of the proposed model alternative. These criteria consist of a business training program for silk, raw material supply, human resource development innovation (knowledge, skills, and attitudes), government policies (supervision), company involvement (national and multinational), and capital for silk business needs.

The weighting of each criterion involved in AHP analysis can be calculated manually or using the help of Expert Choice v11 software. Weighting using Expert Choice v11. The Eigenvector Calculation Table and the Maximum Eigenvalues and Consistency Ratio value testing results from weighting using Expert Choice v11, it can be seen that the final result of data processing based on the AHP method is a training program $=0.249$, raw material supply $=0.211$, HR development innovation $=0.178$, government policy $=0.169$, company involvement $=0.135$ and venture capital $=0.122$. 
Furthermore, the consistency ratio value also varied from one another. The training program's weight is 0.044 ; motivation is 0.033 , HR development innovation is 0.010 , government policy is 0.021 , company involvement is 0.014 , and venture capital is 0.000 , which means it has significant consistency where the $\mathrm{CR}$ (consistency ratio) value must be < 0.05 . For the dominant priority, weight is business capital as a priority decision in the spinning business development model. The result of the global importance of each selected alternative is model 2 (0.411). Model 2 has more excellent value than model $1(0.313)$ and model 3 (0.306). In this case, model 2 has a better preference than model 1 and model 3 for all existing criteria. This case happens cause model 2 is superior from each of the requirements than model 1 and model 3. While the ECM analysis results, the ranking of decisions that must take precedence is obtained, namely venture capital, innovation in human resource development, company involvement, government policies, and the supply of raw materials and training programs.

The following is a discussion of the results of the Third Phase research, which discusses the business development model based on the priority order obtained from the AHP and ECM analysis results.

\subsection{Provision of Business Capital}

The success of MSMEs in conducting operations is very dependent on the availability of business capital as the locomotive of business dynamics. Including in the silk business development, farmers, silk artisans, downstream, and upstream entrepreneurs need sufficient business capital to be used in their operations. On that basis, the existence of MSMEs is beneficial for business actors engaged in the silk industry and is the main reason for every silk entrepreneur to run and pursue their business if given sufficient capital to develop thebusiness. The theory of capital structure from Margaretha (2014) [3] states that companies develop according to their long-term capital structure and capital. The capital structure does not affect firm value, but it does affect the company's operational activities. The application of capital structure concerning the development of lending business is known as the longterm capital structure theory and tax capital structure. Business actors want loan capital to strengthen the capital structure by using business tax-free.

Working capital theory by Sawir (2014) [4] states that working capital is the total current assets owned by a company. These assets are funds that must be available to finance business operations daily. That is why business actors, in developing their business, really need current assets to finance all their business activities following the company undertaken. Silk entrepreneurs need funds to carry out purchasing activities before carrying out making silk weavers produce marketable silk products.

Both theories are supported by the concept of capital decisions put forward by Brigham and Houston (2016) [5]. Four factors determine capital structure decisions: business risk, tax position, financial flexibility, conservatism, and management aggressiveness. These four factors will be good or bad, depending on the capital structure owned by the company. On that basis, this concept is a concern for entrepreneurs to prioritize venture capital in developing a spinning business.

\subsection{Human Resource Development Innovation}

The scooter business development model requires human resource development 
innovations. These namely, entrepreneurs can run and pursue a spinning business using people who are skilled in the field of silk and take advantage of modern silk technology to produce quality silk. Currently, in reality, there is still a tendency for entrepreneurs to retain traditional ways of doing silk contemplation, which should haveshiftedtomodernmethods by adopting creative human resource development innovations by utilizing computerized technology in their operations.

According to Carriolo (2016), management theory can be defined as someone's knowledge is managed to produce the best thoughts and works [6]. This definition means that in the development of the spinning business, innovation in learning management-oriented human resource development is needed. For instance, the emerging of business actors in scooting can think and produce the best work in the field of silk, especially the results of practical, technical, and tactical thoughts by providing quality and superior work.

Hence, because it requires competent people, people who have competence in their fields are human capital who contribute to the company. The competencytheory put forward by Donald (2017) states that a person's ability can be seen in four window frames, namely knowledge (knowledge), skills, experience (expert), and attitude (attitude) [7]. The more competent a person is, the more visible the level of profound knowledge is following the expertise of the skills possessed by experience in the work field by showing an attitude of mastering the developed business. On that basis, business actors in the midwife looking for and selecting people who have the competence to compete.

Competition in the business sector is an absolute thing because the management of companies engaged in the scooting industry must know the concept of race. According to Algerow (2017), competition is a strategic effort to win and gain an advantage [8]. The importance of this competition for business actors is to make various efforts with a marketing strategy that can be constructively analyzed to win business competition according to the level of profit achieved. That is why the concept of race is needed to innovate HR development to make scooting business progress and develop.

\subsection{Involvement of National and Multinational Companies}

Developing a scooting business requires various parties' involvement in strengthening the company's economic access, including the participation of national and multinational companies in enhancing the development of synergy companies to become independent and competitive companies. This company support strengthens corporate institutions, corporatefinance, corporatemarketing, and organizational capital ownership. That is why an integrated partnership is needed in providing an existence for the development of a synergy company to become a national and multinational company.

The partnership theory put forward by Thoby (2016) [9] partnership is a business strategy of two or more parties within a specified period to get benefits and benefits together with the principle of mutual need and agreement basis. This theory is essential considering that in competition, cooperation and empowerment are needed that mutually strengthen each business to get benefits and benefits by making partnerships, namely by including national and multinational companies in improving the development of silk companies.

In principle, partnership activities carried out by more than two companies involving national and multinational companies are carried out to obtain benefits. The theory of benefits from Karren (2017) that every agreement is made to get benefits [10]. Advantages are crucial considerations in carrying out an activity or business transaction, 
both specifically beneficial in the form of profits and gains in general in the way of development, empowerment, and progress of companies based on partnerships that use each other to achieve common goals. It has implications for the business development model of the business.

Partnerships and benefits are essential because they provide benefits. That is why it is necessary to strengthen the mutual interest concept from Harsey (2016), a partnership in which more than two companies will mutually benefit by providing benefits and profits [11]. This concept offers an important point that mutual benefit efforts can be realized if there has been a reciprocal agreement to provide mutual benefits and benefits, as evidenced by a fair and equitable distribution by prioritizing the realization of goals above each other's interests. That is the importance of developing business advancement by applying a business development model by involving national and multinational companies.

\subsection{Government Policies to Promote the Scooters Business}

The development of a synergy business requires government support through policies that are easy to implement and evaluate to advance the start of a thriving company with a healthy business climate. Government policies in improving this scooter include policies related to the ease of obtaining capital by involving banking or financial institutions, supporting partnering with various MSMEs and systems in developing innovation and technology.Governmentpolicyisasolutioninanswering multiple problems faced by cuter business actors.

The policy theory from Dye (2008) that the government does or does not have to do [12]. This policy means that the government has the authority or power to carry out various theories related to programs or activities related to aspects of development to improve community welfare, including policies in business development through programs/activities applied to MSMEs. It means that government policies for censorship actors can be accommodated in various MSMEs' activities in determining the development model of the business.

In addition to policy theory, a development program theory from Marchovic (2015) is needed, development programs must be actualized in behavior between lower- level organizations and target groups [13]. This theory means that government policies must be implemented in various programs or activities that involve inter- organizational practices. In this case, the employers and companies related to synergy products, lower-level practices that use joint programs in realizing entrepreneurial goals between farmers, business actors, and the government and involving behaviors. The target group, in this case, the silk business actors to play an essential role in the business activities of the silk business to increase their income and welfare.

Based on the theory above, it is relevant to the concept of welfare from Whingert (2016) [14] that health is the goal of government policy in development activities. Prosperity can be realized by the fulfillment of all matters relating to the needs of individuals or companies in business development, including people who are involved as actors in the field of censorship get rights and guarantees to pursue the business of scooping to increase their income and welfare. Prosperity is the ultimate goal of a whistleblower business in supporting the business development model.

\subsection{Raw Material Supply for Silk}


Every silk company and scooting business should always consider the availability of the much-needed silk raw material, namely the availability of silk cocoon, which can be used as silk thread spun, which is an essential availability in silk manufacture. Currently, the supply of raw materials for domestic silk is still available. Some silk raw materials at certain times require imported raw materials from abroad. The amount of raw material for silk is an essential consideration for business sustainability and guarantees its existence to develop its business today and in the future.

The theory of demand from Friedman (2000) stated that he lower the price of an item, the more need for that good [13]. This theory means that determining a product's price is strongly influenced by the availability of raw materials for the product. The more silk products are produced, the easier the price is affordable by consumers, which causes the level of demand to increase. Supply theory by Friedman (2000) stated that price and quality determine the supply of a product [13]. Therefore, buyers' and sellers' behavior and interaction are determined mainly by supply and demand. Offer high if the product price is high and the quality is excellent.

Conversely, the offer is low if the product price is low, and the product quality is poor. The amount and quality of silk are very much determined by the materials used. Therefore, the guarantee of the supply of goods is essential toensure that the level of demand and supply of products at the marketing level can be controlled and stabilized. It becomes a consideration in influencing the business development model of the business.

The concept of a trading system was put forward by Khol and Uhl (2015) in business activities where there is a flow of goods and services from the point of production to consumers' end [15]. Carrying out trade system activities involves various approaches in the form of an institutional approach, a functional approach, a goods approach, and a systems approach. An institutional strategy is to strengthen the trade system chain from one market institution to another, either in the form of producers, wholesalers, and retailers or, in other words, from institutions of silk farmers, traders, collectors, and entrepreneurs. The functional approach is a trading system based on the exchange function, physical procurement of materials, and smooth supply function from one place to another. The goods approach emphasizes the trading system activities that move goods from one place to another. The systems approach, namely, organizing the business work system from sub-system to other sub-systems such as from the inter-regional, domestic, and international silk marketing system.

\subsection{Workforce Training Program in the field of silk}

This workforce training program in the scooter is vital to practice one's talents, instincts, and professionalism in developing a business to become advanced and developing. A workforce training program as a training program that can analyze business activities, business profits, and business strategies must be carried out to realize company goals. Including, in this case, the spinning companies that have been promoted need the touch of competent people in the field of scooting, particularly human resources who have participated in various workforce training programs oriented to the business development model of the business.

This workforce training program's importance is supported by training theory, simulation theory, and business development concepts. Training theory from Norton (2017) [16] training programs is a necessity for developing HR competencies. Companies always need competent people in their fields of work, so a training program is required that leads to various forms of stimulation of activities that are oriented towards increasing one's ability in entrepreneurship. 
Training theory is an essential prerequisite for everyone to develop their potential in business, including in the business sector.

The simulation theory put forward by Dunga (2017) that training programs always produce practical simulations in doing business [17]. The training program becomes relevant if each trained member can demonstrate his intellectual and functional abilities in developing a spinning business. The government or companies must find and select the right people to take part in employment training programs to avoid a shortage of competent people in their fields. This training program is in line with the placement of the right people in their areas of work. This also means that people who have participated in the business development program are required to manage the business's development.

The importance of workforce training and simulation programs to the business development model is creating integrated business development. The concept of business development, according to Jhingan (2016), advanced businesses exist in people who understand the idea of business development [18]. The approach includes building a business, managing a business, increasing business income, and becoming a national business. This is expected from the concept of business development in the industry, namely that many entrepreneurs are engaged in the filing of the market, can manage the filing business professionally, generate revenue from the business, and become national and multinational companies in the field of spinning.

\section{Conclusion}

Based on the research's result, it is concluded that the assessment of the criteria that determine the decision of the business development model from the results of the hierarchical analysis of the process selected six principles which are the eligibility to be considered in making the right decision on the business development model. The six criteria include training programs for silk craftsmen, the supply of silk raw materials, innovation in developing human resources in the field of silk, supporting government policies in advancing the business of spinning off, the involvement of national and multinational companies and the availability of capital for the spinningindustry.

Determining the ranking of decisions for the right model in the scooting business in Wajo Regency can be used as a decisive decision according to the results of the exponential comparison method. It is obtained the decision to provide business capital as a top priority to be applied in the business development model of the business. Furthermore, innovating human resource development to improve silk craftsmen's knowledge, skills, and attitudes. Also, it is essential for the involvement of both national and multinational companies in advancing the silk business, supporting government policies in developing silk businesses, and supplying silk raw materials and creating training programs for workers for the sustainability of silk businesses in thefuture.

Based on the conclusions above, it is operational advice/recommendations that business development's success is inseparable from the ability of business feasibility and business behavior to apply the results of its evaluation in creating a market orientation. Besides, they should have the ability to develop following the creation of customer relationships in encouraging business actors to make decisions for business development. It is integrated into the synergy business in Wajo Regency. Considering the six priority criteria in making decisions on the business development model of the synergy, so the 
model can be applied in advancing the business in Wajo District.

The ranking decision results found business capital was necessary to provide money that supported the business activities of the silk industry, then made innovations to develop the competence of silk artisans, opening upopportunities for national and multinational companies to participate in advance. In the synergy business, it is also necessary to increase supervision as a form of government support in advancing the silk business, increasing the supply of silk raw materials, and creating training programs for workers in the silk sector in Wajo Regency.

\section{Referensi}

[1] Emory, P. en Cooper: Antecedents And Concequences Of Business Strategy Making: A Model And A Test, J. Bus. Manag., vol 63, bll 18-40, (1991).

[2] Singarimbun:Metodologi Penelitian. Yogyakarta: Andi, (1995).

[3] Margaretha:Mengukur Kemampuan Bisnis Kewirausahaan. Tangerang: Penerbit Kharisma, (2014).

[4] Sawir en Agnes:Strategi Manajemen Bisnis. Jakarta: Penerbit Kencana, (2014).

[5] Brigham en Houston:How to Managed of Financial Statement. New Jersey, Prentice Hall, (2016).

[6] Carriolo, Y.:Business Development-Making Reexamined. San Francisco: Chandler Publishing Company, (2016).

[7] Donald, G.:Human resource management. Cengage AU, (2019).

[8] Katz, A.:Foundation of Behavioral Business independency. New York: Prentice Hall, (1972).

[9] Thoby en Daniel: Entrepreneurship And Business Strategy: The SME Under Globalization, J. Int. Mark., vol 8, no 2, bll 12-32, (2016).

[10] Sharpe, K.:The Partnership: Relation in Enterpreneur. Prentice Hall, Ohio University Press, (2016).

[11] Harsey, G.:The Element of Administration Development. Ithaca: Cornell University Press, (2016).

[12] Dye, T. R.:The irony of democracy: An uncommon introduction to American politics. New Jersey: Prentice Hall, (2008).

[13] Marchovic, S.:Analyzing public policy, 10th editi. Prentice Hall, Ohio University Press., (2015).

[14] Whingert: The Sustainability Of The Entrepreneurial Orientation-Performance Relationship, Entrep. Theory Pract., vol 24, no 1, bll 37-47, (2016).

[15] Davies, K. en E. Baron, U.:Affected of Product, Price, Promotion and Place toward The Satisfaction and Customer Value in Prudential Company. Cengage Learning, (2015).

[16] Norton en Davis: The Effects Of Entrepreneurial Productivity On Business Performance, J. Bus. Manag., vol 66, bll 18-32, (2017).

[17] Dunga:Autonomy in Concept and Theory of Business independency. American Press, USA., (2017).

[18] Jhingan:Marketing and Strategy in Marketing. Kanada: McMIllan, (2016). 